\title{
The Role of Higher Education in National Quality Infrastructure Policy-Making
}

DOI: 10.7595/management.fon.2017.0003

\begin{abstract}
The aim of the paper is to raise awareness of the importance of the policy makers' knowledge and expertise about quality infrastructure (QI) for the successful policy-making. This article, which addresses the role of higher education in Serbian quality infrastructure policy-making, is an analysis of QI related contents of higher education institution curriculum. The target institutions are public faculties from whose official websites the data were collected. Depending on the keywords, the analysis was performed in order to classify the faculties into three categories. After reviewing the 307 subject titles and descriptions of undergraduate courses, the results show that the concepts of QI are widely recognized as an important and popular topic. The analysis of the QI adoption and diffusion indicates that although some of the faculties might be 'leaders' in a particular dimension, they still do not necessarily fall into the 'leader' category.
\end{abstract}

Keywords: higher education, syllabi, knowledge, quality infrastructure, policy-making, Serbia JEL Classification: I21, I23, H54, L15

\section{Introduction}

In the modern business world quality and standards are extremely important instruments for the achievement of an organization's competitive advantage. Most countries have developed an entire industry of service providers that specialize in the diffusion of quality and standards. Hence, the modern university faces the challenge of adjusting to a complex world with new demands for professions and skills associated with quality. Also, universities have a unique role in deepening and expanding human knowledge (through learning and research) (Ferrer-Balas et al., 2010). At the same time, it is important to remember that faculties are the places where future leaders, entrepreneurs, policy-makers, and scholars are being prepared (Lozano, 2006). Through the development of higher education in Serbia, from the first step in the history of higher education, the main goal was to produce experts to meet the needs of industry and society (Slavkovic and Eisuke, 2009). Quality is definitely given due consideration in the higher education process in Serbia and there are also faculties which develop the quality management and standardization courses. However, education in the QI field is a basic prerequisite for the successful building and improvement of the National Quality Infrastructure (hereinafter referred to as: NQI) in every country and an essential policy-making impact factor. The extent to which Ql is important in the processes of policy-making and political decision-making, subsequently emphasizes the importance of policy makers' knowledge and expertise. This article, which addresses the role of higher education in the Serbian quality infrastructure policy-making, is an analysis of QI related contents of higher education institution curriculum (see Lozano, 2010). Hence, we analyze the titles and contents of compulsory and optional subjects using faculties' official web pages. Although the results show that the concepts of quality and standards are widely recognized as an important and popular topic, only a few departments develop and offer compact and recognizable QI modules focused on quality, standards, accreditation, metrology and conformity assessment. The aim of the paper is to raise awareness of the importance of the policy makers' knowledge and expertise about quality infrastructure for the successful policy-making. If the quality infrastructure is not treated in the right manner, quality in the whole country will suffer. 
The paper is organized into five sections. After the introduction, the second section briefly introduces national quality infrastructure policy-making and describes policy makers' knowledge, explaining to what extent their educational background impacts decisions and policy making processes. The research methodology used in the study is explained in section three, while the fourth section includes the results and the discussion. Finally, the fifth section offers some concluding remarks and guidelines for future research.

\section{National Quality Infrastructure Policy-Making and Application}

For years, policy makers' misuse of information regarding different issues (including quality), along with a lack knowledge and experience, has undermined public trust. This is especially true in relation to policy makers' capability of perceiving and dealing with real-world problems and important issues, such as quality infrastructure. In today's business environment, a functioning QI is a prerequisite for an access to regional and global markets. "Quality infrastructure is the totality of the institutional framework (public or private) required to establish and implement standardization, metrology (scientific, industrial and legal), accreditation and conformity assessment services (inspection, testing, and product, system certification) necessary to provide acceptable evidence that products and services meet defined requirements, be it demanded by regulatory authorities (technical regulation) or the market place (contractually or inferred)" (Kellermann, 2011). The mentioned activities "provide an essential link to global trade, market access and export competitiveness as they contribute to consumer confidence in product safety, quality, health and the environment" (Pejovic et al., 2011). Also, NQI is important for the international recognition of products and services and their further competitiveness and, correspondingly, it is significant for exports. Therefore, we can say that establishing a good quality infrastructure is a step towards good governance which creates a favourable trade climate in the region. "Good governance is understood as good political framework conditions, rule of law and the responsible handling of political power and public resources by the state and thus an important precondition for poverty alleviation and ensuring sustainable development" (Physikalisch Technische Bundesanstalt, 2007).

Accreditation plays a vital role in the NQI system. It is a formal confirmation that a body is competent enough to perform certain tasks (Shaukat, 2010), or what makes the certifications, and thus the quality, trustworthy. It builds confidence in the work of testing laboratories, certification and inspection bodies, and facilitates mutual recognition of certificates, in addition to the promotion of trade (lbid.). No less important QI elements are „metrology", which ensure that measurements are made with appropriate accuracy and reliability (Choi et al., 2014), and "standards", as a tool in free trade and conformity assessment. "Standards are a significant factor in who wins and who loses in the global market place" (Bhatia, 2011; cited by Mijatovic, 2014) and the standardization strategy for developing countries is to adopt standards first and improve capabilities. "Conformity assessment is associated with quality and it can be used to assess the quality if explicit requirements for product quality exist" (Liepiòa et al., 2014). Ribeiro et. al, (2016) stress that conformity assessment is needed to verify the compliance with standards. It is necessary that all these QI elements are connected through QI institutions that communicate with regional and international ones, thus making an invisible global network (See Figure 1).

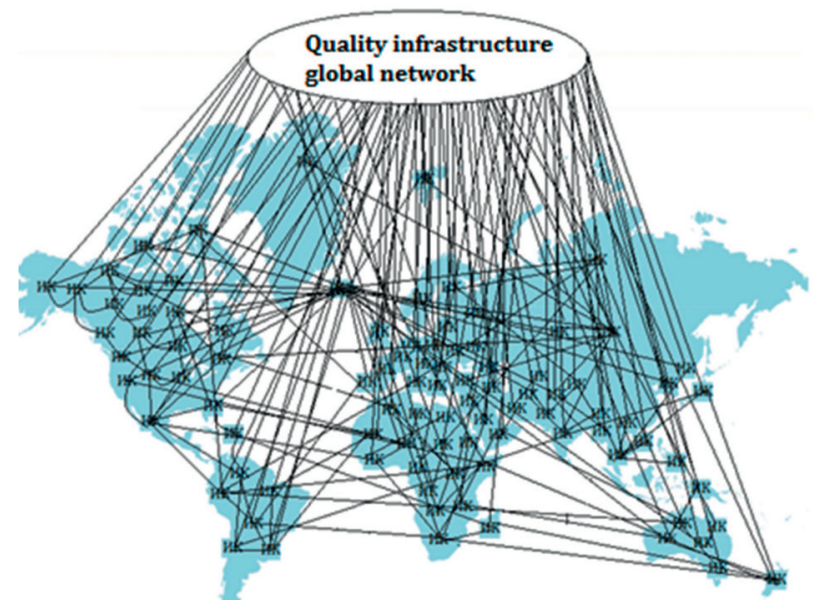

Figure 1: The quality infrastructure global network (Ruso et al., 2016) 


\subsection{Knowledge and Policy Makers}

Lee et al. (2011) claim that "knowledge is what shapes the beliefs and drives the decisions" of policy makers. The prerequisite for NQI policy-making and a country's successful development is policy makers' generalized as well as specialized knowledge. Similarly, Knezevic and Veselinovic (2015) state that "competitiveness of the economy primarily depends on outcomes of education, in the sense of shaping such innovative and creative capacities among individuals who are profiled through education and are enabled for fast adjustment to global technology development trends". Therefore it is important to investigate where and how this knowledge is gained. Hulnick (1986) defines policy makers as government officials (institutions) who formulate, choose, and implement policy, and Newman et al. (2016) describe policy makers as „action oriented, practical persons concerned with obvious and immediate issues“. In the decision making process, policy makers' education and professional experience are important because they are more likely to distinguish good advice from bad and might be more able to resist the pressure of lobbying groups. In the article "How are Serbian politicians tempered", Radun (2013) claims that our political elite are semieducated regardless of formal education, that they lack experience and usually do not confer with science, whereas only a few people involved in politics are from practical spheres. Similarly, Lammintakanen and Kinnunen (2004) interpret that "politicians have limited knowledge about what constitutes true efficiency or quality... and what knowledge they have is seldom based on scientific research". Turner (1980) also argues that lack of knowledge has made policy makers unfit to address major national issues. Nonetheless, Guasch (2007) states that a deficiency in one factor, such as education, cannot always be compensated with quality awareness. It is a mix of different factors such as knowledge, experience, skills, political position, ideology and interest which run initiatives and shape policy makers' views.

However, quotations from Pitman (2012) are especially selected in order to illustrate the educational visions of Australian federal politicians in their first speeches to Parliament. Interestingly, he observes that political speeches about education are connected to different themes, one of them being 'quality'. In favour of the research, Pitman (2012) shows that although politicians have struggled to define what exactly quality in education is, they are very definite that it needs to be improved.

Analyzing whether the educational and professional backgrounds of heads of government influence the implementation of reforms, Dreher et al. (2009) show that reforms are significantly more likely when the politician has an entrepreneurial or scientific background and vice versa. They claim that entrepreneurs are strong leaders and have a proven record of experience in leading a company and have basic knowledge of the issue, while trained and educated policy makers are more rational and less emotional in decision making. However, the research was limited to heads of government in the economic field. Similarly, Jones and Olken (2004) find a positive relation between the education of leaders and the rate of growth, and Besley et al. (2011) find that more educated politicians generate higher growth. Mikosch and Somogyi (2008) quoted by Dreher et al. (2009), find that political leaders with an educational background in economics generate significantly lower budget deficits than those educated in the field of law. Accordingly, we can say that "more educated politicians are better" (World Bank, 2005) in the policy-making process. In reality, such a knowledge base allows them to locate that knowledge in a broader social and political context. All this indicates that education in the quality infrastructure field is essential, because uneducated or incompetent policy makers in this area may lead to an increase in the number of inappropriate decisions. Hence, in the next section we will position faculties within the QI network.

\section{Higher Education in Relation to Serbian Quality Infrastructure Policy-Making}

Dramatic and drastic changes in social circumstances and the tempting idea of European integration provided an appropriate setting for higher education reform (Despotovic, 2011). Higher education institutions are public institutions that represent an important link in improving and building national quality infrastructure (See Ruso et al., 2015). The modern university faces the challenge of adjusting to a complex world with new demands for professions and skills associated with the knowledge society. Academic community must quest after an innovative way of connection between higher education institutions and the community, predominantly through the modernization of curricula (Milutinovic and Nikolic, 2014). To successfully meet these important challenges, it is fundamental that universities' governing bodies have good relations with the academic community in order to respond to the social and productive needs of its environment (Espinoza 
and González, 2013). The idea of institutions of higher education working on producing quality management experts is paramount (Milosevic et al., 2013) and crucial for the success of NQI policy-making.

Figure 2 illustrates QI institutions and the relationships among them. The principal institutions in the QI network are the Directorate of Measures and Precious Metals, the Accreditation Body, the Institute for Standardization, the Ministry of Economy (QI department) and conformity assessment bodies. The institutions involved in the periphery (dashed blue line) are the Ministry of Trade, Tourism and Telecommunications, the Ministry of Finance, the Ministry of Agriculture and Environmental Protection, the Ministry of Education, Science and Technological Development, the Chamber of Commerce and Industry and faculties. The connections between faculties and other institutions are multiple. For instance, faculties educate people (future societal leaders, decision-makers and intellectuals) in the QI field who are employed in other relevant institutions in Figure 2. The mobility of students, experts and lecturers should be encouraged. QI experts can be engaged in teaching, whereas institutional cooperation allows students to work as interns and volunteers in Quality Management and Standardization sectors. Also, universities shall promote networks of QI stakeholders with the aim of collaborating on common QI national and international projects in both research and education. Finally, many initiatives at the national level should be launched by University lecturers (policy initiatives as well).

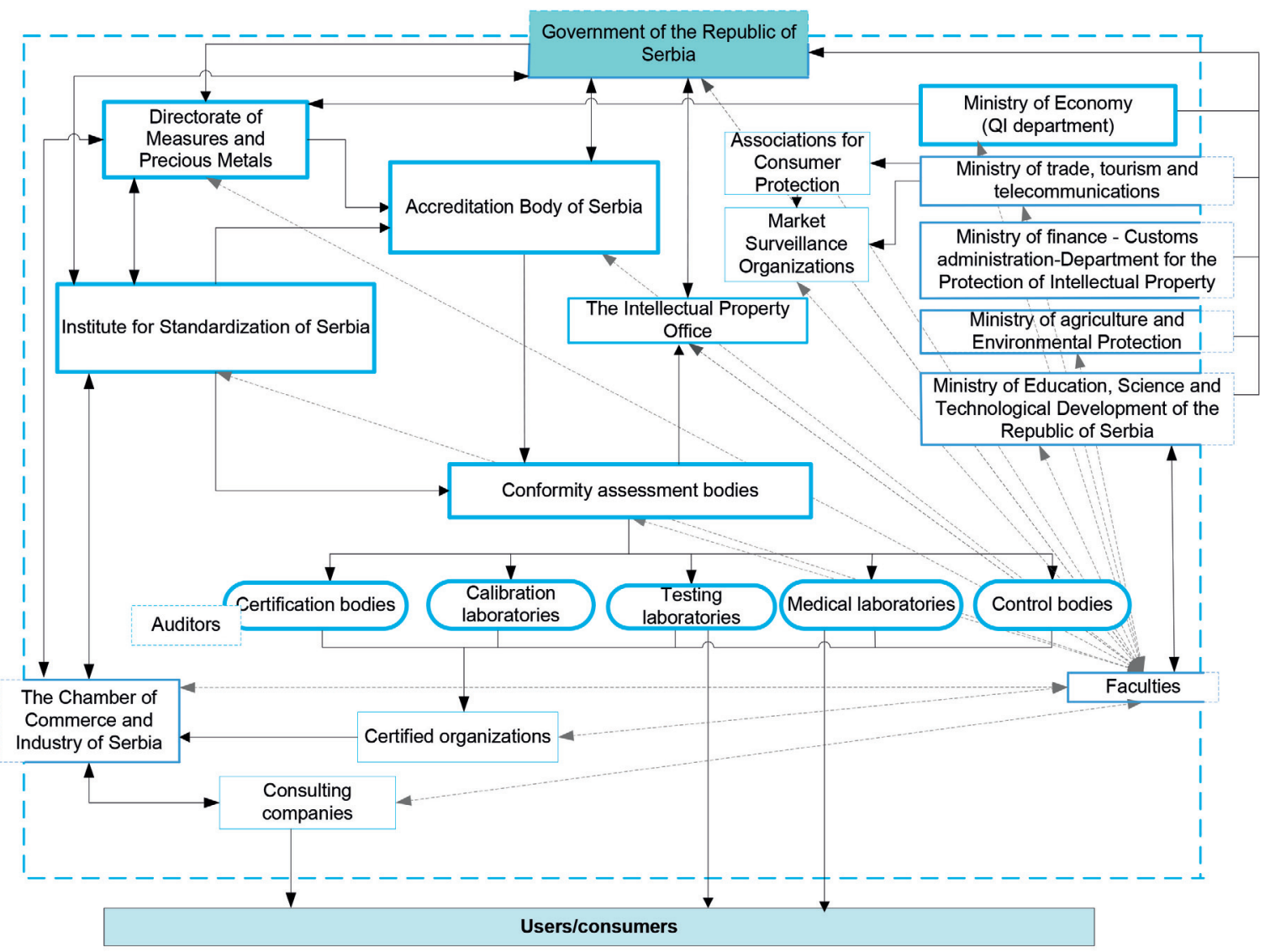

Figure 2: Quality infrastructure institutions and the integration role of faculties (Source: Authors' presentation)

Although universities may not be the cause of many of our current problems, they may contribute to them, especially through the production of knowledge and education (Conceiçao et al., 2006; quoted by FerrerBalas, 2010). People who have degrees in QI are more competent to plan, control, improve and assure quality, take initiatives and make policy at all decision making levels. Therefore, quality infrastructure and its elements should be recognized as a crucial topic of study in the Republic of Serbia. With the aim of investigating the current state, we carried out research to show whether the Serbian higher education system recognizes $\mathrm{QI}$ as an important and necessary part of the syllabus. 


\section{Methodology}

The subjects of analysis were the titles and descriptions of 307 syllabi from 19 public faculties including only undergraduate courses (the University of Belgrade, University of Novi Sad, University of Kragujevac and University of Niš). To avoid any attempt to rank faculties according to the results, their names were not published. One of the selection criteria for public faculties were courses accreditation, because good practice has shown that the accreditation system is an appropriate way to organize a national educational system and „to improve and assure the quality of the services” (Cerqueira, 2006). The accredited courses provide that higher education institutions satisfy specific standards of educational quality (Mekasha, 2005). The data were gathered from the official web sites chosen according to the appropriate category, using publicly available information. Depending on the QI keywords, the analysis was performed in order to classify the faculties into three categories (Table 1) (Similar to Arafeh, 2016).

Table 1: Categories and Key Words

\begin{tabular}{|l|l|}
\hline Categories & Key words \\
\hline Category I & quality, standard, standardization, accreditation, metrology \\
\hline Category II & control, measure, production, technology, management, business, environment \\
\hline Category III & marketing, sales, trade, market, transport, and trade laws \\
\hline
\end{tabular}

In category I we grouped those faculties whose subject titles directly indicate QI elements such as metrology, standardization, quality and accreditation (curricula that contain a minimum of 5 subjects). The faculties whose subjects are also important for this issue were grouped within category II (curricula that contain a minimum of 10 subjects). The subjects from this category shape perception about QI as they provide enough knowledge to understand and manage problems related to the topic. However, the titles of these subjects do not contain QI elements therefore they are not recognised as a group of faculties which directly indicate QI components. Finally, category III included those faculties which provide basic knowledge of the issue at an introductory level (curricula that contain a minimum of 4 subjects).

\section{Results and Discussion}

The QI issues are incorporated in curricula of almost every university in Serbia. The results show that the courses with QI contents are present at a number of engineering departments and at some humanities, but still lacking at humanistic departments. Similar to Wilkinson and Yussof (2005) we include fields of study (Table 2). The results show that faculties from categories I and II belong to the technical and technological group of faculties, whereas within category III there are present technical and social faculties. This, however, is expected since "the first standard of quality assurance (BS 9000) was developed for the electronics industry" (Cevere et al., 2008). One faculty is present in both categories (I and II) due to the distribution of the subjects according to the keywords in Table 1. This is not surprising because, according to students' rewards and successes (The Case Study Show, 2016), perennial awards for the best institution for the education of managers (promulgated by the Serbian Association of Managers, 2016) and the ranking list of the best faculties in Serbia (Students' Ranking of Faculties, 2014), this faculty is the leading public higher education institution in the field of management.

The analysis of the education curriculum and syllabi is widely studied in different areas such as sustainability (Milutinovic and Nikolic, 2014; Poon and Poon, 2017; Dmochowski et al., 2016), environment (Lammel et al., 2014), and chemistry (Glassey and Haile, 2011). Similarly to Arafeh (2016) and Perera and Hewege (2016), we also measured the frequency of appearance of the keywords in the course titles. For example, out of the 307 syllabi reviewed, 'quality' was mentioned 65 times, 'standard/standardization' 5 times and accreditation only 3 times. Within category II 'control' was mentioned 67 times, 'management' 45 times and 'inspection' 28 times. 
Table 2: Faculties and subjects (Bachelor programmes)

\begin{tabular}{|c|c|c|c|}
\hline Categories & Faculties & Subjects & Fields of study \\
\hline Category I & $\begin{array}{l}5 \text { technical and } \\
\text { technological } \\
\text { faculties }\end{array}$ & $\begin{array}{l}\text { - standardization, } \\
\text { - metrology, } \\
\text { - accredited laboratories, } \\
\text { - quality control, } \\
\text { - quality planning, } \\
\text { - quality costs, } \\
\text { - the fundamentals of quality, } \\
\text { - quality systems, } \\
\text { - quality control of industrial products, } \\
\text { - quality assurance systems in production, } \\
\text { - quality control of the environment, } \\
\text { - quality inspection and environment control, } \\
\text { - quality standards, } \\
\text { - statistical quality control, } \\
\text { - techniques for quality improvement, } \\
\text { - normative regulation of quality, } \\
\text { - quality control in agribusiness, etc. }\end{array}$ & $\begin{array}{l}\text { Engineering and } \\
\text { Technology }\end{array}$ \\
\hline Category II & $\begin{array}{l}5 \text { technical } \\
\text { faculties }\end{array}$ & $\begin{array}{l}\text { - production systems, } \\
\text { - management of key production } \\
\text { performance, } \\
\text { - cost control, } \\
\text { - risk control, } \\
\text { - sales management, } \\
\text { - packaging and food packaging, } \\
\text { - the management of the food industry, } \\
\text { - business management systems, } \\
\text { - production management, } \\
\text { - process management, } \\
\text { - merchandising, } \\
\text { - measurement and control processes in the } \\
\text { metallurgical industry, } \\
\text { - protection management systems, etc. }\end{array}$ & $\begin{array}{l}\text { Engineering and } \\
\text { Technology }\end{array}$ \\
\hline Category III & $\begin{array}{l}2 \text { technical } \\
\text { faculties; } \\
2 \text { faculties of } \\
\text { social sciences }\end{array}$ & $\begin{array}{l}\text { - transport of goods, } \\
\text { - the fundamentals of logistics, } \\
\text { - supply chains, } \\
\text { - Serbia's economic relations with foreign } \\
\text { countries, } \\
\text { - trade marketing and sales management, } \\
\text { - international business and management, } \\
\text { - foreign trade operations, } \\
\text { - international commercial law, } \\
\text { - trade law, etc. }\end{array}$ & $\begin{array}{l}\text { Economics, Law, } \\
\text { Medicine }\end{array}$ \\
\hline
\end{tabular}

However, the key point from the results is that although some schools indicate 'leaders' in the QI dimension they are not necessarily the only ones in the overall higher education system. The reason for that is that some faculties offer QI subjects that are probably not obvious at first glance. This does not mean that they do not directly target QI subjects, and in that sense, some of the faculties from category II could be classified in category I. Therefore, we observe that the results are methodology dependent. They just show approximately where the topic is studied, and the keywords do not allow us to penetrate the subjects' content more deeply. 
Conclusion

Depending on their educational and professional backgrounds, policy makers manage to deal with real-world problems and important issues such as quality infrastructure. Establishing a good QI is a step towards good political framework conditions and the rule of law. Also, it leads to the responsible handling of political power and public resources. We will agree that acquired knowledge is what shapes the beliefs and drives the decisions of policy makers. Better-educated policy makers cope better with the implementation of reforms and they are more rational and less emotional in decision making. Therefore it is important to investigate their educational background, which is of high importance to QI policy-making in Serbia.

Higher education in Serbia has rarely been the subject of systematic research and consequently there is a lack of data related to the issue. Most articles have been written recently and have been clearly connected to quality assurance in higher education. Hence, with the intention of investigating the role of higher education in NQI policy-making, we analyzed curricula and indicated the importance of educated policy makers. The subjects of analysis are public universities from whose official web sites the data were collected. Depending on the QI keywords, research was carried out in order to classify the faculties into three categories. The results show that only three faculties offer more than five QI subjects within category I. Those faculties which indirectly target QI elements are grouped into category II and also include five technical faculties. Ultimately, category III includes subjects at the introductory level that refer to market, marketing, trade, trade laws, supply chains, logistics etc. In a nutshell, the results suggest that the greatest number of subjects belongs to category II. Only a few faculties have a department with a large number of mandatory subjects connected to quality infrastructure. We need to keep in mind that the results are methodology dependent, providing us with a basic insight into the current situation in the Republic of Serbia, while the keywords selection might be a limiting factor too.

Additionally, the results have certain limitations due to the availability of syllabi. For example, some faculties do not have all syllabi available on their web site. Also, the research does not include master and PhD studies and focuses only on the state faculties. Therefore, the limitations are suggested as an area for future research. Likewise, there is a possibility of carrying out new research studies in the Balkans and comparing them with the Serbian higher education program related to QI elements such as quality, standardization, certification, accreditation and conformity assessment. In addition, the students from the Quality Management and Standardization Departments could be interviewed and asked for their opinions about the subjects in comparison with market needs for expertise in the above mentioned fields. Quality experts could also express their attitudes about the education system in Serbia and these could be compared with the students' opinions. The output and outcome of this research could help policy makers, politicians, scholars, experts, organizations as well as investors to understand how quality and standards are perceived and considered in higher education in Serbia, and how important they are in NQI policy-making.

\section{Acknowledgements}

Parts of this paper have been presented at the XV International Symposium SYMORG 2016 "Reshaping the future through sustainable business development and entrepreneurship", Zlatibor, Serbia, 2016.

\section{REFERENCES}

[1] Arafeh, S. (2016). Curriculum mapping in higher education: a case study and proposed content scope and sequence mapping tool. Journal of Further and Higher Education, 40(5), 585-611. doi: 10.1080/0309877X.2014.1000278

[2] Besley, T., Montalvo, J. G., and Reynal-Querol, M. (2011). Do Educated Leaders Matter?, The Economic Journal, 121(554), F205-227. doi: 10.1111/j.1468-0297.2011.02448.x.

[3] Bhatia, J., (2011). Summary Report of 2011 Joint Meeting of the APEC Sub-Committee on Standards and Conformance (SCSC)'s in APEC Sub - Committee on Standards and Conformance (SCSC) APEC Committee on Trade and Investment. APEC SCSC Education Guideline 4 - Case Book Teaching Standardization in Universities: Lessons Learned from Trial Program

[4] Cerqueira, M. (2006). A literature review on the benefits, challenges and trends in accreditation as a quality assurance system. Victoria, British Columbia: Ministry of Children and Family Development.

[5] Cevere, R., Sproge, S., and Arhipova, I. (2008). How to use an experience of the development of ISO 9001 sertified quality system in study process improvement. In Proceedings of the International Scientific Conference, Jelgava, Latvia, 10-12 April, 2008 .126. 
[6] Choi, D. G., Hyun, O. S., Hong, J. I. and Kang, B. G. (2014). Standards as catalyst for national innovation and performance-a capability assessment framework for latecomer countries. Total Quality Management \& Business Excellence, 25(9-10), 969-985. doi: 10.1080/14783363.2014.893082

[7] Conceiçao, P., Ehrenfeld, J., Heitor, M., and Vieira, P. S. (2006). Sustainable universities: fostering learning beyond environmental management systems. International Journal of Technology, Policy and Management, 6(4), 413-440. doi: 10.1504/IJTPM.2006.011725

[8] Despotovic, M. (2011). The interpretation and implementation of the Bologna Process in Serbia. European Education, 43(3), 43-55. doi: http://dx.doi.org/10.2753/EUE1056-4934430303

[9] Dmochowski, J. E., Dmochowski, J. E., Garofalo, D., Garofalo, D., Fisher, S., Fisher, S., ... and Gambogi, D. (2016). Integrating sustainability across the university curriculum. International Journal of Sustainability in Higher Education, 17(5), 652-670. doi: 10.1108/IJSHE-10-2014-0154

[10] Dreher, A., Lamla, M. J., Lein, S. M., and Somogyi, F. (2009). The impact of political leaders' profession and education on reforms. Journal of Comparative Economics, 37(1), 169-193. DOI: 10.1016/j.jce.2008.08.005

[11] Espinoza, Ó., Eduardo González, L. (2013). Accreditation in higher education in Chile: results and consequences. Quality Assurance in Education, 21(1), 20-38. doi: 10.1108/09684881311293043

[12] Ferrer-Balas, D., Lozano, R., Huisingh, D., Buckland, H., Ysern, P., and Zilahy, G. (2010). Going beyond the rhetoric: system-wide changes in universities for sustainable societies. Journal of Cleaner Production, 18(7), 607-610. doi: 10.1016/j.jclepro.2009.12.009

[13] Glassey, J., and Haile, S. (2012). Sustainability in chemical engineering curriculum. International Journal of Sustainability in Higher Education, 13(4), 354-364. doi: 10.1108/14676371211262308

[14] Guasch, J. L. (2007). Quality systems and standards for a competitive edge. World Bank Publications.

[15] Hulnick, A. S. (1986). The intelligence producer-policy consumer linkage: A theoretical approach. Intelligence and National Security, 1(2), 212-233. doi:

[16] Jones, B. F., and Olken, B. A. (2004). Do leaders matter? National leadership and growth since World War II. National Leadership and Growth Since World War II (March 2004).

[17] Kellermann M., (2011). Thoughts on a National Quality Policy, Physikalisch Technische Bundesanstalt, Braunschweig-Germany.

[18] Knezevic, M., and Veselinovic, P. (2015). New education policy's priorities as a function of economic development of Serbia. Ekonomika, 61(1), 151-159. doi: 10.5937/ekonomika1501151K

[19] Lammel, G., Comas, E. J., and Ivancev-Tumbas, I. (2014). Higher education in environmental sciences with chemistry emphasis: bachelor and master programmes in Europe. Environmental Science and PolIution Research, 21(11), 7211-7218. doi: 10.1007/s11356-014-2737-7

[20] Lammintakanen, J., and Kinnunen, J. (2004). Social and health care priorities of local politicians in Finland: Do the attitudes of politicians reflect the actual processes in municipalities? International Journal of Social Welfare, 13(1), 69-76. doi: 10.1111/j.1369-6866.2004.00298.x

[21] Lee, D., Loutas, N., Sánchez-Nielsen, E., Mogulkoc, E., and Lacigova, O. (2011). Inform-consultempower: a three-tiered approach to eParticipation. In International Conference on Electronic Participation,121-132. Springer Berlin Heidelberg.

[22] Liepiòa, R., Lapiòa, I., and Mazais, J. (2014). Contemporary issues of quality management: relationship between conformity assessment and quality management. Procedia-Social and Behavioral Sciences, 110, 627-637. doi: 10.1016/j.sbspro.2013.12.907

[23] Lozano, R. (2006). Incorporation and institutionalization of SD into universities: breaking through barriers to change. Journal of cleaner production, 14(9), 787-796. doi: 10.1016/j.jclepro.2005.12.010

[24] Lozano, R. (2010). Diffusion of sustainable development in universities' curricula: an empirical example from Cardiff University. Journal of Cleaner Production, 18(7), 637-644.doi: 10.1016/j.jclepro.2009.07.005

[25] Mekasha, K. (2005). Ensuring the quality of Ethiopian higher education in the face of the challenges of the 21st Century. Ethiopian Journal of Higher Education, 2(2), 103-131.

[26] Mijatovic, I. (2014). The Need for Standardization in SMEs Networks. Management, 73, 35-40. doi: 10.7595/management.fon.2014.0028

[27] Mikosch, H. F., Somogyi, F. S. (2008). Individuals vs. institutions. The impact of political leaders' education and profession on public deficits, ETH Zurich, mimeo.

[28] Milosevic, D., Djuric M., Filipovic, J., and Ristic, S. (2013). Benchmarking as a quality management tool in public administration. Engineering Economics, 24(4), 364-372. doi:

[29] Milutinovic, S., and Nikolic, V. (2014). Rethinking higher education for sustainable development in Serbia: an assessment of Copernicus charter principles in current higher education practices. Journal of Cleaner Production, 62, 107-113. doi: 10.1016/j.jclepro.2013.05.028 
[30] Newman, J., Cherney, A., and Head, B. W. (2016). Do Policy Makers Use Academic Research? Reexamining the "Two Communities" Theory of Research Utilization. Public Administration Review, 76(1), 24-32. doi: 10.1111/puar.12464

[31] Pejovic, G., Filipovic, J., and Tasic, L. (2011). How to remove barriers to medicines trade in emerging economies: the role of medicines regulatory authority in Serbia. Accreditation and Quality Assurance, 16(4-5), 253-261. doi: 10.1007/s00769-010-0749-7

[32] Perera, C. R., and Hewege, C. R. (2016). Integrating sustainability education into international marketing curricula. International Journal of Sustainability in Higher Education, 17(1), 123-148. doi: 10.1108/IJSHE-03-2014-0041

[33] Physikalisch Technische Bundesanstalt (2007). Values and rules for global responsibility Quality infrastructure: a step towards Good Governance, Germany

[34] Pitman T., (2012), Selling visions for education: What do Australian politicians believe in, who are they trying to convince and how?, Australian Journal of Education, 56(3) 226-240

[35] Poon, J., and Poon, J. (2017). Engaging sustainability good practice within the curriculum design and property portfolio in the Australian higher education sector. International Journal of Sustainability in Higher Education, 18(1), 146-162. doi: 10.1108/IJSHE-09-2015-0149

[36] Radun B. (2013). "How are the Serbian politicians tempered", Politika, Retrieved on from November 27,2016

[37] Ribeiro, A. S., Costa, A. C., Candeias, P., e Sousa, J. A., Martins, L. L., Martins, A. F., and Ferreira, A. C. (2016). Assessment of the Metrological Performance of Seismic Tables for a QMS Recognition. In Journal of Physics: Conference Series, 772(1), p. 012006, IOP Publishing.

[38] Ruso, J., Filipovic J., and Pejovic, G. (2016). The role of higher education in building and improving national quality infrastructure - The case of Serbia. In XV International Symposium SYMORG, June 10-13, Zlatibor, Serbia, 1220-1224

[39] Ruso, J., Horvat, A., Djuric, M., and Trajkovic, A. (2015). Quality infrastructure in higher education-The case of Serbia, In the Proceedings of the International Conference on Education and Modern Educational Technologies, July 16-20, 2015, Zakynthos Island, Greece, 135-139

[40] Serbian Association of Managers, (2016), Retrieved on December, 16 2016from

[41] Shaukat H., (2010). Industrial competitiveness through quality infrastructure, Pacistan national accreditation council Retrieved from

[42] Slavkovic, G., and Eisuke K., (2009). Adaptation of Serbian University to Bologna Process. Nagoya Higher Education. 9: 257-276

[43] Student Ranking of Faculties (2014), The best faculties 2014 - General ranking list, Retrieved on December, 162016 from http://www.studentranking.org/sr/najbolji-fakulteti-2014-generalna-rang-lista

[44] The Case Study Show, (2016), Retrieved on December, 162016 from

[45] Turner F. M. (1980). Public Science in Britain, 1880-1919. Isis, 71(4), 589-608. Retrieved from

[46] Wilkinson, R., and Yussof, I. (2005). Public and private provision of higher education in Malaysia: A comparative analysis. Higher Education, 50(3), 361-386. doi: 10.1007/s10734-004-6354-0

[47] World Bank, (2005). The political economy of Gram Panchayats in South India: Results and policy conclusions from a research project, Edward Elgar Publishing Limited, UK. 


\title{
$1 / 1 / 1 / 1 / 1 / 1 / 1 / 1 / 1 / 1 / 1 / 1 / 1 / 1 / 1 / /$ abouthe author
}

\author{
Jelena Ruso \\ University of Belgrade, Faculty of Organizational Sciences \\ jelena.ruso@fon.bg.ac.rs
}

MSc Jelena Ruso is a PhD student he Faculty of Organizational Sciences, University of Belgrade - Department of Quality Management and Standardization. She has published several scientific research papers in international and national journals and conference

proceedings. Jelena has primarily focused on quality management aspects in public administration. Also, she has participated in several national and international projects (e.g. TEMPUS, WUS). Since 2012, she has been engaged in project of the Ministry of Education, Science and Technological Development. Moreover, Jelena teaches courses on fundamentals of quality and quality control.

\section{Jovan Filipović \\ University of Belgrade, Faculty of Organizational Sciences jovanf@fon.bg.ac.rs}

Dr Jovan Filipovic is a Quality management lecturer and Head of the Quality Management and Standardization Department at the Belgrade University, Faculty of Organizational Sciences. He earned his Ph.D. and MSME from Purdue Univesity (USA),

School of Mechanical Engineering and BSME from the Belgrade University School of Mechanical Engineering. He also earned another Ph.D. from the University of Ljubljana

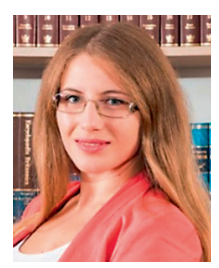

(Slovenia), Faculty of Public Administration.

\section{Gordana Pejović \\ University of Belgrade, Faculty of Organizational Sciences pejovic.gordana@fon.bg.ac.rs}

Dr Gordana Pejović is assistant professor at the Faculty of Organizational Sciences, University of Belgrade - Department of Quality management and Standardization. She earned a B.Sc and M.Sc degrees at the Faculty of Pharmacy, University of Belgrade, and a Ph.D. degree at the Faculty of Organizational Sciences, University of Belgrade.

Currently, she also holds the position of the Quality Management Manager at the

Medicines and Medical Devices Agency of Serbia. In her academic career, she has primarily focused on quality management, accreditation and quality management

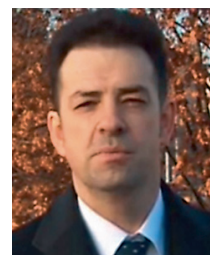
aspects of health care. 